\title{
The impact of hunting with dogs on wildlife harvests in the Bosawas Reserve, Nicaragua
}

\author{
JEREMY KOSTER* \\ Department of Anthropology, University of Cincinnati, PO Box 210380, Cincinnati, OH 45221-0380, USA \\ Date submitted: 15 April 2008; Date accepted: 17 September 2008
}

\section{SUMMARY}

Although they are used throughout the Neotropics, the impact of dogs on the composition of wildlife harvests has received little systematic attention. In the Bosawas Biosphere Reserve of Nicaragua, indigenous hunters rely heavily on dogs to locate prey. Hunting harvest data over a year-long period in two indigenous Mayangna and Miskito communities indicate that the use of hunting dogs is significantly associated with the harvests of several terrestrial mammalian species. The use of dogs is also a significant predictor of the extent to which the species composition of harvests deviates from Neotropical averages. Although dogs appear to have little effect on the sex profiles of harvested game species, the use of dogs is significantly associated with hunting in agricultural landscapes. From a conservation perspective, the disadvantages of dogs include their indiscriminate pursuit of prey species, including species that hunters would not otherwise pursue. Advantages of dogs include their relative ineffectiveness in pursuits of species that are particularly vulnerable to overhunting, such as primates and white-lipped peccaries (Tayassu pecari). Hunting dogs may be an economical option for many Neotropical societies, and their role in wildlife management plans merits increased attention from conservationists.

Keymords: dogs, garden hunting, Mayangna, Miskito, subsistence hunting, sustainability, wildlife conservation

\section{INTRODUCTION}

After habitat loss, hunting is widely recognized as the most significant threat to faunal biodiversity in the Neotropics (Alvard et al. 1997; Bodmer et al. 1997). Although conservationists advocate protected areas without human use (Redford \& Sanderson 2000), much of the remaining forest exists in areas that have been used for centuries by rural peoples, particularly indigenous societies (Redford \& Mansour 1996). In many of these settings, hunted game is an important source of dietary protein, and the absence of

*Correspondence: Dr Jeremy Koster Tel: +1 5135560020 e-mail: jeremy.koster@uc.edu sufficiently inexpensive alternatives often makes the reduction of wildlife harvests problematic (Milner-Gulland et al. 2003). Given the reliance of rural peoples on hunted game, conservationists have responded by promoting sustainable harvests of wildlife species (Robinson \& Redford 1994). The focus on hunting patterns has become increasingly important in recent decades as integration into external markets, technological enhancements, increased population growth and sedentism, and the loss of hunting areas to incursions by outside settlers have altered the traditional hunting strategies of once isolated societies (Stearman 2000).

The conservation implications of hunting with firearms have received considerable attention (Alvard 1995a; Mena et al. 2000). By comparison, although researchers have devoted much less attention to the implications of hunting with dogs, the general impression is that dogs are detrimental to conservation efforts. Redford and Robinson (1987) briefly noted that the use of dogs can increase the harvest of certain prey species. At the local level, Ventocilla et al. (1995) blamed the use of dogs for the localized extirpation of several wildlife species in the Panamanian interior. In the Brazilian state of Acre, the use of dogs for hunting is prohibited in some communities (Carneiro da Cunha \& Almeida 2000; Minzenberg 2005). Reports indicate that hunters with dogs sometimes enter wildlife reserves (Koshear 1995; Cullen 1997).

Despite these concerns, there are remarkably few data on the effects that dogs have on wildlife harvest profiles. Observational evidence suggests that dogs primarily aid hunters not by killing prey, but rather by detecting animals and by flushing them into locations (i.e. burrows, hollow trunks, waterways) where hunters can attack them (Alvard \& Kaplan 1991; Koster 2008a). In an optimal foraging analysis of Mayangna and Miskito hunters, Koster (2008a) showed that both encounter rates and the profitability of prey types can vary dramatically between hunters with dogs and hunters without dogs; hunters with dogs encountered approximately nine times as many agoutis as unassisted hunters, and nocturnal species such as pacas (Cuniculus paca) and nine-banded armadillos (Dasypus novemcinctus) were typically encountered on day trips only when hunting with dogs (Koster 2008a). Given those differences, it is reasonable to infer that the species composition of harvests varies between hunters with dogs and hunters without dogs.

Despite the importance of dogs in locating prey, however, reports of wildlife harvests typically indicate the technologies used to kill prey animals with less regard to how they were first 
detected. For instance, some report data on the percentage of prey killed by dogs, but not the number of animals corralled or flushed by dogs (Townsend 2000; Ohl-Schacherer et al. 2007). Other reports indicate the overall percentage of kills in which dogs provided assistance, but their harvest data do not indicate which species are particularly associated with the use of dogs (Smith 1976; Jorgenson 1993).

These latter data are important because wildlife species vary in their susceptibility to overhunting and depletion, in large part owing to variation in life history characteristics (Bodmer et al. 1997). In addition, adult females have greater reproductive value than other age-sex classes (Alvard 1995b; Leeuwenberg \& Robinson 2000), and it is worthwhile to determine whether adult females are disproportionately represented in harvests by hunters with dogs. There has also been recent attention to hunting in agricultural landscapes (Daily et al. 2003; Smith 2005; Gavin 2007), in part because focused hunting in these areas could relieve pressure on wildlife populations in nearby mature forests.

Fast-breeding adaptable species tend to predominate in anthropogenic habitats (Escamilla et al. 2000; NaughtonTreves et al. 2003), and Robinson and Bennett (2004) therefore suggested that biomass production in these habitats may exceed production in unmodified forest habitats. Accordingly, Gavin (2007) argued that hunting in anthropogenic habitats has greater potential for sustainable harvests. Yet, few studies have addressed the relationship between hunting technology and the geographic distribution of hunting. Although empirical data are limited, there are preliminary indications that dogs are comparatively valuable in the anthropogenic habitats near settlements (Sirén et al. 2004).

A setting in which hunters use multiple hunting technologies represents a natural experiment that allows researchers to investigate the relationship between technologies and the species composition of harvests. This study tests the hypothesis that the use of dogs is associated with variance in the composition of harvests in the Bosawas Reserve, Nicaragua. This paper also examines the effects of hunting with dogs on the sex ratio of harvested prey and the geographic distribution of kill sites. The sustainability of the harvest is assessed using the production model of Robinson and Redford (1991). Finally, the possibilities for incorporating dogs into wildlife management plans are discussed.

\section{Study area}

Nicaragua's Bosawas Biosphere Reserve, first created in 1991, is part of the largest tract of tropical rainforest north of Amazonia (Stocks 1996). In 1993, The Nature Conservancy (TNC) assisted the land claims of the indigenous people (the Mayangna and Miskito) living in the reserve as they contended with incursions from non-indigenous settlers (Stocks 2003), culminating in the presentation of legal land title to the Reserve's five indigenous territories in May 2005 (Stocks 2005).

This research was based in Kipla Sait Tasbaika, one of those territories. Specifically, I worked in two communities,

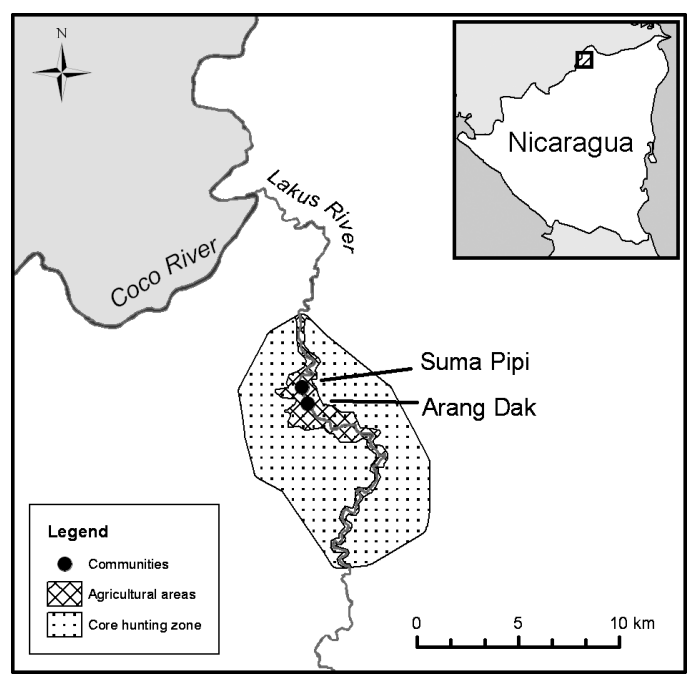

Figure 1 The location of the study area and the core hunting zone, including agricultural landscapes.

Arang Dak and Suma Pipi (Fig. 1). The populations of Arang Dak and Suma Pipi are 170 and 70, respectively. Situated along the Lakus River, a tributary of the Coco River, Arang Dak is located at $85^{\circ} 0^{\prime} 0^{\prime \prime} \mathrm{W}, 14^{\circ} 30^{\prime} 56^{\prime \prime} \mathrm{N}$. Suma Pipi is located approximately one kilometre downstream of Arang Dak. The Lakus River flows from the undeveloped core of the Reserve, and there are no permanent settlements upstream of Arang Dak. Much of the Lakus River watershed is characterized by mature forest cover (Stocks et al. 2007). Although the area was largely uninhabited during the ContraSandinista conflict (Nietschmann 1990), the communities have been continuously occupied since residents returned from Honduran refugee camps in 1991.

Dogs and 0.22-calibre rifles are the principal hunting technologies; machetes, lances and axes are also used, depending on the circumstances. Bows are designed for fishing and are seldom employed by hunters. Blowguns are altogether absent, and traps are used only to kill jaguars that attack village livestock. Hunting is primarily a male-oriented activity, but women occasionally kill game opportunistically. The hunters acquire most of the harvest on short trips originating in the community, although hunting parties sometimes embark on multi-day expeditions up the Lakus River, reaching a maximum distance of approximately 28 kilometres from the community. Nocturnal hunting is generally rare, but at certain times of the year a few hunters target pacas at night by waiting with a flashlight and a rifle at known feeding spots, particularly breadfruit trees (Artocarpus altilis). Similarly, hunters might visit their fields after dusk to ambush crop-raiding species such as deer, tapirs or raccoons.

The Mayangna and Miskito do not consider many of the species that they encounter to be edible. Among mammals larger than $1 \mathrm{~kg}$ in the Lakus River watershed, more than half are not eaten by residents of Arang Dak and Suma Pipi. Included in these aversions are most carnivores, opossums 
and all Xenarthrans with the noteworthy exception of the nine-banded armadillo (see Koster 2008 $a$ for further details). Although the meat of spider monkeys (Ateles geoffroyi) is highly regarded, only a few families consume capuchin (Cebus capucinus) and howler (Alouatta palliata) monkeys, and hunters with rifles regularly bypass these last species despite evidence that pursuing them would raise the rate at which they acquire meat (Koster 2007). Similarly, the meat of the coati (Nasua narica), the forest rabbit (Sylvilagus brasiliensis) and the puma (Puma concolor) is eaten by only a relatively small fraction of community members. Several species are killed to protect domestic animals, and a visiting hunter killed a caiman (Caiman crocodilus) in part because he hoped to sell the skin in his native Honduras.

\section{METHODS}

\section{Hunting records}

Indigenous research assistants were recruited to monitor the community for incoming fish and game resources. The assistants were provided spring scales and clipboards with data forms. Because of its larger size, three employees shared assistantship duties in Arang Dak, each working every third day. On the designated work day, employees would remain in the community during all daylight hours, ready to weigh incoming wildlife and fill out questionnaires. In Suma Pipi, there was one assistant, who was required to be present in the community from dawn until 07:30 and from 16:00 until darkness (when most of the resources were brought into the community). During the interim period, a woman in the community (the assistant's spouse) weighed any incoming fish and game, noting also the sex of hunted game. Upon returning to the community, the assistant from Suma Pipi would then add these data to the form and complete the interview with the hunter in question.

The hunting questionnaires included data on the hour of departure and return to the community, the names of participants, the technologies and dogs taken by each participant, and other resources brought back to the community (such as bananas and firewood). Hunting forms also included questions on encounters with possible prey items (including those that were not pursued), with specific questions pertaining to the number of animals encountered, whether the animal was pursued (and if not, why not), how many shots were fired (if applicable) and why the pursuit was abandoned (if applicable). For animals that were killed, the assistants also recorded the sex, weight and the technologies used to kill the prey item. Following a methodology developed by Smith (2003), the research assistants also drew sketch maps of kill sites by interviewing hunters and relating the sites to known landmarks, such as trails, fields, streams and ridgelines (see Koster 2007 for more details on the sketch mapping process). For their participation in the study each month, households received the equivalent of a day's pay for agricultural labour.
Assistants were trained to work independently, but I also helped with numerous forms, especially on days when I was simultaneously collecting time allocation data. In total, I helped with $39 \%$ of the hunting forms. On days when the assistants in Arang Dak worked independently, I reviewed data sheets at the end of the day to look for errors or omissions. Data sheets from Suma Pipi were reviewed once per week, as the smaller number of forms made this time frame feasible.

Community members occasionally returned home after dark with fish or game, and they were hesitant to seek out the assistants to complete a form. To minimize data lost in such situations, each household was provided a clipboard and a weekly food form. At the beginning of each workday, assistants would visit each household to help fill out the form with the female head of household. For each day of the week, the form listed all regular sources of animal protein: hunted game, fish, beef, pork, poultry, eggs and milk. If one of the items had been consumed, assistants would record the type (for example species of wild game), amount, how it was acquired, the price (if applicable) and the original owner (in the case of gifts and purchases). If wild meat reported on the food forms lacked a corresponding hunting data form, the assistants would visit the household in question to collect the data. Because it was not possible at such times to weigh the hunted animal, either averages of already-weighed specimens or published estimates were used to calculate the harvested biomass.

After an initial training period, data collection in Arang Dak lasted from 1 September 2004 to 31 August 2005. For Suma Pipi, data are presented from 15 December 2004 to 31 August 2005. Because Suma Pipi participated in the study for less than a year, their annual harvest was estimated by projecting the observed harvest over an additional three and a half months.

\section{Sustainability model}

To explore the sustainability of the harvest, I used the production model of Robinson and Redford (1991). Because the maximum sustainable yield (MSY) values in this model are considered overestimates (Milner-Gulland \& Akçakaya 2001), documented harvests that exceed these values ostensibly demonstrate locally unsustainable exploitation. However, because actual population densities of wildlife species may be less than the model's predicted densities, the model cannot be used to conclusively demonstrate that harvests are sustainable.

The projected annual harvest in this sustainability assessment includes animals that were reported injured during the study period, including two tapirs, two collared peccaries, two white-lipped peccaries, one red brocket deer, one spider monkey and two great tinamous (see Table 1 for species names).

An important component in the model is the size of the hunting zone (Alvard et al. 1997). To estimate the size of the hunting zone, I created a polygon in ArcGIS 9.2 that encompassed all kills made by hunters on day-long hunting trips from Arang Dak or Suma Pipi. I then buffered 
Table 1 Species composition of wildlife harvested in Arang Dak and Suma Pipi, by number, biomass and percentage of total biomass.

\begin{tabular}{|c|c|c|c|c|c|c|}
\hline \multirow[t]{2}{*}{ Scientific name } & \multirow[t]{2}{*}{ Common name } & \multicolumn{2}{|c|}{ Arang Dak } & \multicolumn{2}{|c|}{ Suma Pipi } & \multirow{2}{*}{$\begin{array}{l}\text { \% of total } \\
\text { biomass }\end{array}$} \\
\hline & & Number (n) & $\overline{\text { Biomass }(\mathrm{kg})}$ & Number (n) & $\overline{\text { Biomass (kg) }}$ & \\
\hline Tapirus bairdii & Baird's tapir & 13 & 2338 & 1 & 166.5 & 29.99 \\
\hline Dasyprocta punctata & Agouti & 350 & 1031.1 & 13 & 32 & 12.73 \\
\hline Tayassu pecari & White-lipped peccary & 20 & 744.9 & 9 & 218 & 11.53 \\
\hline Cuniculus paca & Paca & 115 & 848.8 & 6 & 39.7 & 10.64 \\
\hline Tayassu tajacu & Collared peccary & 39 & 768.2 & 1 & 24 & 9.49 \\
\hline Dasypus novemcinctus & Nine-banded armadillo & 155 & 645.6 & 8 & 25.8 & 8.04 \\
\hline Mazama americana & Red brocket deer & 15 & 215.8 & 3 & 42.5 & 3.09 \\
\hline Panthera onca & Jaguar & 3 & 194 & & & 2.32 \\
\hline Myrmecophaga tridactyla & Giant anteater & 4 & 160 & & & 1.92 \\
\hline Odocoileus virginianus & White-tailed deer & 1 & 49 & 2 & 98 & 1.76 \\
\hline Iguana iguana & Iguana & 54 & 123.6 & 2 & 4.2 & 1.53 \\
\hline Ateles geoffroyi & Spider monkey & 11 & 76.2 & 3 & 20.5 & 1.16 \\
\hline Penelope purpurescens & Crested guan & 38 & 72.3 & 2 & 2.9 & 0.90 \\
\hline Crax rubra & Great curassow & 16 & 45.6 & 6 & 15.4 & 0.73 \\
\hline Puma concolor & Puma & 2 & 59.5 & & & 0.71 \\
\hline Tinamus major & Great tinamou & 48 & 45.1 & 3 & 3.2 & 0.58 \\
\hline Alouatta palliata & Howler monkey & 5 & 35 & & & 0.42 \\
\hline Leopardus pardalis & Ocelot & 2 & 30 & & & 0.36 \\
\hline Trachemys scripta & Slider turtle & 15 & 29.2 & & & 0.35 \\
\hline Nasua narica & Coati & 8 & 24.4 & & & 0.29 \\
\hline Rhinoclemmys funerea & Black wood turtle & 10 & 23.1 & & & 0.28 \\
\hline Caiman crocodilus & Caiman & & & 1 & 15.5 & 0.19 \\
\hline$?$ & Unidentified turtles & 7 & 10.5 & 2 & 1.9 & 0.15 \\
\hline Tamandua mexicana & Northern tamandua & 2 & 12 & & & 0.14 \\
\hline Procyon lotor & Northern raccoon & 1 & 9.2 & & & 0.11 \\
\hline Cebus capucinus & Capuchin monkey & 3 & 7.8 & & & 0.09 \\
\hline Kinosternon leucostomum & White-lipped mud turtle & 15 & 7.6 & & & 0.09 \\
\hline Amazona spp. & Parrots & 7 & 3.8 & 3 & 2.9 & 0.08 \\
\hline Ramphastos smainsonii & Chestnut-mandibled toucan & 6 & 3 & 1 & 0.5 & 0.04 \\
\hline Ramphastos sulfuratus & Keel-billed toucan & 6 & 3.4 & & & 0.04 \\
\hline Galictis vittata & Greater grison & 1 & 3 & & & 0.04 \\
\hline Crypturellus soui & Little tinamou & 7 & 2.2 & 1 & 0.6 & 0.03 \\
\hline Rhynchortyx cinctus & Tawny-faced quail & 7 & 2.5 & & & 0.03 \\
\hline Geotrygon spp. & Doves & 7 & 1.7 & 2 & 0.4 & 0.03 \\
\hline Ara spp. & Macaws & 1 & 1 & 1 & 1 & 0.02 \\
\hline Ortalis vetula & Plain chachalaca & 7 & 2 & & & 0.02 \\
\hline Sciurus variegatoides & Variegated squirrel & 5 & 1.4 & & & 0.02 \\
\hline Tigrisuma mexicanum & Bare-throated tiger-heron & 1 & 1.3 & & & 0.02 \\
\hline$?$ & Unidentified birds & 3 & 1.3 & & & 0.02 \\
\hline Cochlearius cochlearius & Boat-billed heron & 2 & 1.1 & & & 0.01 \\
\hline Dryocopus lineatus & Lineated woodpecker & 3 & 0.8 & & & 0.01 \\
\hline \multirow[t]{2}{*}{ Crypturellus boucardi } & Slaty-breasted tinamou & 1 & 0.5 & & & 0.01 \\
\hline & Total & 1016 & 7635.5 & 70 & 715.5 & 100.00 \\
\hline
\end{tabular}

this polygon an additional $500 \mathrm{~m}$ to account for possible inaccuracies in the sketch mapping process. The result is an oblong polygon with an area of $77.6 \mathrm{~km}^{2}$ (see Fig. 1). Because the production model (Robinson \& Redford 1991) assumes that there is no immigration into the catchment area from unexploited areas, only those animals killed in the core hunting zone are included in the sustainability assessment (thus excluding about $8 \%$ of the animals, which were killed on overnight expeditions outside of the core zone).
Remote sensing and measurements with a global positioning system (GPS) unit indicate that 15\% of the hunting zone is comprised of agricultural areas, including both activelycultivated fields and fallows in various stages of regrowth. These agricultural landscapes are particularly concentrated along both sides of the river.

MSY estimates for white-faced capuchin monkeys, whitetailed deer (Odocoileus virginianus) and Baird's tapir (Tapirus bairdii) were not included in the original publication by 
Robinson and Redford (1991), but it was possible to calculate an estimate for the capuchins and white-tailed deer, as all necessary parameters were available (Robinson \& Redford 1986a, b). Although there are published density estimates for Baird's tapir (Robinson \& Redford 1986b), reproductive parameters were included only for South America's lowland tapir (Tapirus terrestris) (Robinson and Redford 1986a). Data on the reproduction of captive Baird's tapirs (Brown et al. 1994) suggest that the reproductive characteristics of Baird's tapir differ little from those of the lowland tapir (J. Brown, personal communication 2006). The maximum finite rate of natural increase $\left(\lambda_{\max }\right.$ in Robinson \& Redford 1991) would therefore be 1.22 for both species. Following Robinson and Redford (1991), I relied on the regression equations from Robinson and Redford (1986b) to calculate predicted densities needed for the new MSY estimates (see also Koster 2006).

\section{Data analysis}

To gauge the extent to which the harvest of game species is associated with different hunting technologies, kills are classified according to the accessories used to locate and dispatch the animals. The categories do not necessarily reflect the full suite of technologies available to the hunters at the time, only the technologies needed to detect and kill the animal. For example, while hunters with dogs also had rifles in many cases, the guns were seldom used for agouti kills and the kills were therefore classified as 'dog' kills. By contrast, the 'dog and gun' category signifies that both technologies were instrumental in the kill. The 'gun' category indicates that the animal was detected without the assistance of dogs and that rifles were the primary technology used for the kill. It is possible to make a gun kill even when hunting with dogs, as when hunters encounter and kill red brocket deer while their dogs are elsewhere. Finally, the 'other' category applies to kills made without either guns or dogs, usually by hunters using machetes, slingshots, lances or their bare hands. Two iguanas were excluded from the sample because it was not possible to identify the technologies used during the kills.

To test differences in the geographic distribution of kill sites and the sex ratio of harvested game species, Fisher's exact tests were used. However, the sample sizes of some species harvested by hunters without dogs are small, which precludes conclusive interpretations of insignificant results.

SPSS 14.0 was used for statistical testing.

\section{RESULTS}

\section{Total offtake}

Residents of Arang Dak and Suma Pipi killed at least 44 species, including 20 mammalian species, at least 19 species of birds and five reptilian species (Table 1). Both in terms of numbers and biomass, mammals dominate the combined sample, as they comprise $74 \%$ of the animals
Table 2 Numerical harvest of prey types by hunting technologies.

\begin{tabular}{lcrrr}
\hline \hline Prey type & Gun and dog & Dog & Gun & Other \\
\hline Agouti & 4 & 345 & 11 & 3 \\
Game birds & 0 & 3 & 160 & 16 \\
Nine-banded armadillo & 1 & 152 & 1 & 9 \\
Paca & 0 & 112 & 7 & 2 \\
Iguana & 0 & 29 & 11 & 14 \\
Turtles & 0 & 1 & 0 & 48 \\
Collared peccary & 17 & 19 & 3 & 1 \\
White-lipped peccary & 0 & 0 & 27 & 2 \\
Primates & 0 & 0 & 22 & 0 \\
Deer & 1 & 8 & 11 & 1 \\
Baird's tapir & 9 & 2 & 2 & 1 \\
Coati & 6 & 0 & 2 & 0 \\
Variegated squirrel & 0 & 0 & 4 & 1 \\
Uneaten species & 4 & 7 & 5 & 0 \\
Total & 42 & 678 & 266 & 98 \\
\hline \hline
\end{tabular}

killed in the sample and $95 \%$ of the total biomass. The top eight contributors of consumed meat were mammals, and six of those species (tapir, agouti, white-lipped peccary, paca, collared peccary and nine-banded armadillo) together comprise $82 \%$ of the biomass in the overall harvest. Assuming that $65 \%$ of the harvested biomass is edible meat (Hill \& Hawkes 1983), the per caput consumption of wild meat in Arang Dak is $0.09 \mathrm{~kg}$ consumer ${ }^{-1}$ day $^{-1}$ and $0.03 \mathrm{~kg}$ consumer $^{-1}$ day $^{-1}$ in Suma Pipi (Koster 2007). For this calculation, consumers are defined as individuals who are at least 3.5 years old (Alvard 1995a).

Of the 1086 animals taken in the two communities, $41 \%$ (representing $36 \%$ of the biomass) were acquired opportunistically in the course of activities other than hunting. Approximately 53\% of the animals were killed on excursions in which members of the party also brought back bananas, manioc or firewood (although the hunters themselves were not always responsible for their acquisition).

\section{Harvest by hunting technology}

Chi-square testing for independence on the composition of the harvest by hunting technology (Table 2) indicates that the harvest of game species is associated with different technologies $\left(\chi^{2}=1784.2 ; p<0.0001 ; d f=39\right)$. Unsurprisingly, rifles are the weapon of choice when targeting birds and arboreal mammals. By comparison, the three most commonly-killed species (agoutis, armadillos and pacas) are almost overwhelmingly killed with dogs and hand technologies (for example a machete). The combination of firearms and dogs appears to be particularly valuable for hunting tapirs. In total, dogs contributed to $86 \%$ of mammalian prey kills. Among the reptiles, almost all turtles were captured with technologies other than dogs and guns, but more than half of the iguanas were taken with dogs and hand technologies. 
Table 3 Per caput harvest rates (number of harvested animals per consumer) in Arang Dak and Suma Pipi compared to Neotropical norms. ${ }^{*}$ From Peres (2000).

\begin{tabular}{lllr}
\hline \hline Scientific name & This study & Average $^{*}$ & $\begin{array}{c}\text { \% of } \\
\text { average }\end{array}$ \\
\hline Tayassu pecari & 0.145 & 0.674 & 22 \\
Tayassu tajacu & 0.200 & 0.608 & 33 \\
Mazama spp. & 0.090 & 0.307 & 29 \\
Tapirus spp. & 0.070 & 0.052 & 135 \\
Cuniculus paca & 0.605 & 0.806 & 75 \\
Dasyprocta spp. & 1.815 & 0.665 & 273 \\
Sciurus spp. & 0.025 & 0.142 & 18 \\
Alouatta spp. & 0.025 & 0.343 & 7 \\
Ateles spp. & 0.070 & 0.251 & 28 \\
Cebus spp. & 0.015 & 1.072 & 1 \\
Myrmecophaga tridactyla & 0.020 & 0.013 & 154 \\
Tamandua spp. & 0.010 & 0.087 & 11 \\
Dasypus spp. & 0.815 & 0.673 & 121 \\
Nasua spp. & 0.040 & 0.373 & 11 \\
Crax/Mitu spp. & 0.110 & 0.296 & 37 \\
Penelope spp. & 0.200 & 0.543 & 37 \\
Ortalis spp. & 0.035 & 0.015 & 233 \\
Tinamus spp. & 0.255 & 0.250 & 102 \\
Crypturellus spp. & 0.045 & 0.252 & 18 \\
Ara spp. & 0.010 & 0.072 & 14 \\
Amazona spp. & 0.050 & 0.134 & 37 \\
Ramphostos spp. & 0.065 & 0.536 & 12 \\
\hline \hline
\end{tabular}

Compared to a cross-cultural sample of Neotropical harvest profiles, including many studies in which dogs were used sparingly (Peres 2000), the annual per caput consumption in Arang Dak and Suma Pipi was below normal levels for many species (Table 3). For example, none of the primates or Artiodactyls were harvested at more than $33 \%$ of the Neotropical norm. By contrast, the harvest of tapirs, agoutis and armadillos exceeded normal levels. For the 14 mammalian species in Table 3, there was a correlation between the percentage of the Neotropical average and the percentage of harvested specimens that were initially detected by dogs (Table 3; Pearson's $r=0.572 ; p=0.03$ ). In other words, the deviations from Neotropical averages (either positive or negative) were significantly associated with the contributions of hunting dogs.

\section{Sex profiles}

When compared to the harvests of rifle hunters, the use of dogs appears to have relatively little impact on the sex profiles of harvested game species. Of the seven game species that are first detected by either dogs or humans, a Fisher's exact test reveals a significant difference in the sex ratio only for iguanas (Table 4).

However, the understanding of age and sex ratios of Neotropical species remains incomplete (Bodmer \& Robinson 2005). In this study, the female-biased harvest of agoutis deviates significantly from a 1:1 sex ratio $(p<0.001$; Fisher's exact test). Given that almost $97 \%$ of the agoutis in the
Table 4 Harvests of males and females detected by dogs and by humans. The $p$ values are from Fisher's exact tests.

\begin{tabular}{lccc}
\hline \hline Species & $\begin{array}{l}\text { Dogs } \\
\text { Male:female }\end{array}$ & $\begin{array}{l}\text { Humans } \\
\text { Male:female }\end{array}$ & $p$ \\
\hline Dasyprocta punctata & $119: 226$ & $2: 10$ & 0.35 \\
Cuniculus paca & $52: 54$ & $5: 4$ & 0.74 \\
Dasypus novemcinctus & $78: 72$ & $4: 6$ & 0.53 \\
Tayassu tajacu & $18: 16$ & $3: 0$ & 0.24 \\
Tapirus bairdii & $8: 3$ & $2: 1$ & 1.00 \\
Mazama americana & $2: 6$ & $2: 8$ & 1.00 \\
Iguana iguana & $5: 24$ & $11: 14$ & 0.04 \\
\hline \hline
\end{tabular}

combined sample were first detected by dogs, it may be that dogs are particularly adept at locating and corralling females (and their offspring in some cases). However, a test of this hypothesis first requires additional evidence on the actual sex ratio of the agouti population.

\section{Harvest by habitat}

Of the 720 animals captured with the assistance of dogs, $45 \%$ were harvested in agricultural landscapes. By contrast, of the 266 animals harvested by rifle hunters without dogs, 30\% were taken in agricultural landscapes. This difference is significant ( $p<0.001$; Fisher's exact test), which indicates that the use of dogs is associated with agricultural habitats.

\section{Unsustainable harvests}

The sustainability assessment suggests that the harvests of two species, namely tapirs and pacas, are unsustainable in the core zone (Table 5). However, it is noteworthy that, although $61 \%$ of the pacas were harvested in the agricultural zone near the communities, the paca population exhibited few signs of localized depletion. For example, while unsustainable harvests may result in a preponderance of juveniles in the heavilyhunted areas near settlements (Bodmer \& Robinson 2005), there was no correlation between the weight of harvested pacas and distance from the community (Pearson's $r=-0.042 ; p=$ $0.696 ; n=87)$.

It should be noted that the harvest of spider monkeys would also have exceeded sustainable limits if all individuals had been captured in the core hunting zone. In reality, only one spider monkey was taken on a day trip originating in Arang Dak. The remaining individuals in the sample were harvested between 15 and $30 \mathrm{~km}$ from the community by hunters on multiday expeditions. Spider monkeys are rarely encountered near the communities, and previous overhunting is the most likely explanation for their low numbers in the core hunting zone.

Overall, for the ten Neotropical prey types that are found in the Reserve and listed by Robinson (2000), there is a significant correlation between the percentage of harvested animals that were detected by dogs in this study and the maximum percentage sustainable offtake of the population 
Table 5 Projected annual offtake rates in the core hunting zone, compared with estimates of maximum sustainable yield (MSY). ${ }^{\mathrm{a}}$ From Robinson and Redford (1991), see text for details. ${ }^{\mathrm{b}}$ Harvest $>$ MSY.

\begin{tabular}{|c|c|c|c|c|}
\hline Species & Common name & $\begin{array}{l}\text { \% taken in } \\
\text { core zone }\end{array}$ & $\begin{array}{l}\text { Projected annual } \\
\text { harvest }\left(\mathrm{no.} / \mathrm{km}^{2}\right)\end{array}$ & $\begin{array}{l}M S Y^{a} \\
\left(n o . / \mathrm{km}^{2}\right)\end{array}$ \\
\hline Cebus capucinus & White-faced capuchin & 100 & 0.04 & 0.21 \\
\hline Alouatta palliata & Mantled howler monkey & 100 & 0.06 & 0.39 \\
\hline Ateles geoffroyi & Central American spider monkey & 7 & 0.01 & 0.16 \\
\hline Dasypus novemcinctus & Nine-banded armadillo & 97 & 2.05 & 5.19 \\
\hline Sciurus variegatoides & Variegated squirrel & 100 & 0.06 & 44.83 \\
\hline Dasyprocta punctata & Agouti & 99 & 4.71 & 8.98 \\
\hline Cuniculus paca & Paca & 93 & $1.50^{\mathrm{b}}$ & 1.31 \\
\hline Tapirus bairdii & Baird's tapir & 93 & $0.17^{\mathrm{b}}$ & 0.02 \\
\hline Tayassu pecari & White-lipped peccary & 76 & 0.32 & 0.83 \\
\hline Tayassu tajacu & Collared peccary & 98 & 0.53 & 2.41 \\
\hline Mazama americana & Red brocket deer & 100 & 0.25 & 0.67 \\
\hline Odocoileus virginianus & White-tailed deer & 33 & 0.01 & 0.95 \\
\hline
\end{tabular}

(Spearman's $\rho=0.747 ; p=0.013 ; n=10$ ). That is, the prey species that are particularly associated with the use of dogs tend to be those that can withstand comparatively high offtakes.

\section{DISCUSSION}

\section{Hunting dogs and conservation}

From a conservation perspective, there are both advantages and disadvantages to the use of hunting dogs. An obvious disadvantage is that dogs are very effective at detecting many terrestrial species, including agoutis, pacas, nine-banded armadillos, collared peccaries and tapirs. Evidence suggests that the rate at which several of these species are encountered when hunting with dogs is considerably greater than the encounter rates of rifle hunters (Koster 2008a), and the harvest data suggest that the hunting of these animals is closely associated with the use of dogs. Iguanas are also vulnerable to hunters with dogs, and this is especially true when egg-laden females come to the riverside in March.

An additional downside of dogs is their indiscriminate pursuit of wildlife species, including animals that their owners would prefer not to hunt, such as giant anteaters (Myrmecophaga tridactyla), northern tamanduas (Tamandua mexicana) and greater grison (Galictis vittata). The Miskito and Mayangna do not eat these species, and hunters generally kill these animals only when they pose a threat to their dogs (Koster 2008b; see also Hames 1979). Similarly, all of the jaguars were killed following attacks on dogs, and one of the ocelots was killed after an altercation with dogs. Because these feline predators reportedly pose a threat to other domestic animals, the residents of the Reserve attempt to kill them when possible, and the use of dogs seems to increase encounters with the predatory cats, particularly jaguars. The risk of jaguar attacks is one reason hunters with dogs may remain closer to the community than rifle hunters (see also Dunn 2004).
Although useful in pursuits of terrestrial animals, dogs provide little assistance in pursuits of arboreal prey, including primates and game birds (Kaplan \& Kopischke 1992). Because of their comparatively long life history strategies, primates are particularly vulnerable to overhunting (Bodmer et al. 1997). The use of dogs may therefore relieve pressure on these easily overexploited primate populations. Dogs are also little use in pursuits of white-lipped peccaries, which are increasingly endangered in the Neotropics because of hunting and habitat loss (Peres 1996).

In terms of wildlife management, an overall reduction in hunting pressure remains the ideal conservation strategy. For a variety of reasons, however, such reductions may not be feasible in many rural settings (Milner-Gulland et al. 2003). Instead, limitations on the use of certain hunting technologies, especially firearms, may be a worthwhile strategy. Although the subject remains debated, anthropological evidence suggests that hunters harvest comparable amounts of meat regardless of what technologies they use (Hames 1979; Alvard 1995a). Given a constant biomass of hunted game, a harvest profile that is weighted toward species that are routinely hunted with the assistance of dogs may be associated with positive conservationist outcomes. The usefulness of dogs in agricultural areas may also facilitate the establishment of 'notake areas' away from settlements (Sirén et al. 2004).

One challenge to mandating the use of hunting technologies is the hunters' reluctance to forego the use of superior weaponry. For example, hunters may be reluctant to endorse restrictions against rifles and shotguns given the demonstrably superior returns of firearms to traditional technologies, such as bows and blowguns (Stearman 2000). In Arang Dak and Suma Pipi, however, there are no significant differences between the return rates of hunting with only dogs and hand technologies (such as machetes), hunting with rifles and hunting with both dogs and rifles (Koster 2008a). That is, neither rifles nor dogs provide significantly more meat per hour of hunting. Preliminary quantitative data suggest that dogs can be similarly effective at other Neotropical 
sites (Romanoff 1984; Forline 1997), but it is also important to acknowledge reports that dogs are not used for hunting because they detract from the possibilities afforded by hunting with projectile weapons (Wagley 1977; Hugh-Jones 1979; Lizot 1988). Promoting the use of dogs might not be feasible in settings with low densities of species that can be hunted with dogs, such as pacas, agoutis and nine-banded armadillos.

Virtually all Mayangna and Miskito hunters would like to own a rifle, including those who already own dogs. When hunting with dogs, rifles notably increase the likelihood of killing tapirs (and other species to a lesser extent), and the guns also provide a measure of protection against jaguar attacks on the dogs. However, rifles are prohibitively expensive for most households, and only $26 \%$ of the households in Arang Dak and Suma Pipi own a rifle. By contrast, even the poorest households can usually afford to purchase puppies, which are typically sold for the equivalent of a day's labour. As a result, hunting with dogs is frequently the more economical option for many households. If the acquisition costs were sufficiently low, it is likely that other Neotropical societies would welcome additional dogs, especially since they are also valuable as watchdogs and sources of entertainment.

\section{Hunting sustainability}

The unsustainable harvest of tapirs is not surprising, as a number of researchers have reported similar results for lowland tapirs in South America (Bodmer 1994; Alvard et al. 1997; Townsend 2000). Novaro et al. (2000) contended that tapirs persist at these sites because the depletion is balanced by the immigration of animals from unexploited areas, a dynamic known as a source-sink system (Pulliam 1988; see also Salas and Kim 2002). The influx of tapirs from lightly hunted areas upstream of the communities likewise seems to explain the persistence of tapirs in the core hunting zone around Arang Dak and Suma Pipi. This conclusion is consistent with linear transect evidence that tapirs are significantly more abundant as distance from the communities increases (Williams-Guillén et al. 2006).

As with tapirs, it is possible that immigration from unhunted areas is replenishing the paca population in the core hunting zone. Unlike tapirs, however, the linear transect evidence reveals no significant differences between the density of pacas in the heavily-used areas near the communities and the density in rarely-hunted areas (Williams-Guillén et al. 2006). Given the overall absence of localized depletion in the paca population, an alternative explanation is that enhanced foraging opportunities in agricultural areas may allow pacas to exist at comparatively high densities. It is worth noting that researchers have documented pacas' consumption of numerous crops that are common in the reserve, including manioc (Manihot esculenta), maize (Zea mays), bananas and plantains (Musa spp.), cacao (Theobroma cacao), avocados (Persea americana) and peach palms (Bactris gasipaes), some of which are available year-round (Jorgenson 1993; Beck-
King et al. 1999). In addition, jaguars, which prey on pacas (Emmons 1987), exhibit significantly lower densities in highuse areas than in lightly-used areas (Williams-Guillén et al. 2006), which could likewise contribute to relatively high paca densities around the communities. In short, the MSY estimate in the Robinson and Redford (1991) model may underestimate the production of the paca population in this setting.

As noted, the Robinson and Redford (1991) production model cannot be used to confirm that harvests are sustainable because the possibility exists that the densities of wildlife populations are less than the predicted values. However, other than tapirs and pacas, no species is harvested at more than $55 \%$ of the estimated MSY. This suggests that the harvests are likely to be sustainable, and the presence of nearby unhunted areas increases the likelihood of sustainable use.

\section{CONCLUSIONS}

Although they were once absent from much of Amazonia (Schwartz 1997), hunting dogs are now common throughout the Neotropics (Koster 2007). In settings where the costs of firearms and ammunition are prohibitive, hunting with dogs may be a preferred alternative. The increasing fragmentation of Neotropical forests could also increase preferences for hunting dogs because the species that persist in humandominated landscapes are often those that can be hunted with dogs (such as pacas and agoutis) whereas the species that are extirpated locally, such as primates and white-lipped peccaries, are more easily harvested with firearms (Daily et al. 2003). For these reasons, the relative prevalence of hunting with dogs is unlikely to decline in the future. Yet, there has been little systematic research on the impact of hunting dogs on the composition of wildlife harvests. This study indicates that there is a significant association between the use of dogs and the harvest of several terrestrial species, and it is important to collect comparable data at other Neotropical sites.

This research also has implications for applications of catchper-unit effort (CPUE) studies to conservation problems (for example see Vickers 1991). A critical assumption of these diachronic studies is that effort is constant because, if hunting technologies were to change, the measure of offtake per effort would not be constant across time (Bodmer \& Robinson 2005). This study demonstrates that the use of dogs alters the composition of the harvest, and researchers must account for this variable when making comparisons. Additional research on the spatial patterns of hunting and the age-sex profiles of harvested game species will also be needed to fully understand the conservation implications of hunting with dogs.

\section{ACKNOWLEDGEMENTS}

This research was supported by a Fulbright student grant, the National Science Foundation (Dissertation Improvement 
Award \#0413037), the Hill Foundation, and a Sanders Dissertation Grant. I thank the Saint Louis Zoo's Proyecto Biodiversidad for assistance and support throughout my research. Stephen Matter provided thoughtful perspectives on the analysis, and I thank three anonymous reviewers for their comments and suggestions.

\section{References}

Alvard, M. \& Kaplan, H. (1991) Procurement technology and prey mortality among indigenous neotropical hunters. In: Human Predators and Prey Mortality, ed. M. Stiner, pp. 79-104. Boulder, CO, USA: Westview Press.

Alvard, M.S. (1995a) Shotguns and sustainable hunting in the Neotropics. Oryx 29: 58-66.

Alvard, M.S. (1995b) Intraspecific prey choice by Amazonian hunters. Current Anthropology 36: 789-818.

Alvard, M.S., Robinson, J.G., Redford, K.H. \& Kaplan, H. (1997) The sustainability of subsistence hunting in the Neotropics. Conservation Biology 11: 977-982.

Beck-King, H., von Helversen, O. \& Beck-King, R. (1999) Home range, population density, and food resources of Agouti paca (Rodentia: Agoutidae) in Costa Rica: a study using alternative methods. Biotropica 31: 675-685.

Bodmer, R.E. (1994) Managing wildlife with local communities in the Peruvian Amazon: The case of the Reserva Communal Tamshiyacu-Tahuayo. In: Natural Connections: Perspectives in Community-Based Conservation, ed. D. Western \& R.M. Wright, pp. 113-134. Washington, DC, USA: Island Press.

Bodmer, R.E., Eisenberg, J.F. \& Redford, K.H. (1997) Hunting and the likelihood of extinction of Amazonian mammals. Conservation Biology 11: 460-466.

Bodmer, R.E. \& Robinson, J.G. (2005) Evaluating the sustainability of hunting in the Neotropics. In: People in Nature: Wildlife Conservation in South and Central America, ed. K.M. Silvius, R.E. Bodmer \& J.M.V. Fragoso, pp. 299-323. New York, NY, USA: Columbia University Press.

Brown, J.L., Citino, S.B., Shaw, J. \& Miller, C. (1994) Endocrine profiles during the estrous cycle and pregnancy in the Baird's tapir (Tapirus bairdii). Zoo Biology 13: 107-117.

Carneiro da Cunha, M. \& de Almeida, M.W.B. (2000) Indigenous people, traditional people, and conservation in the Amazon. Daedalus 129: 315-338.

Cullen Jr, L. (1997) Hunting and biodiversity in Atlantic forest fragments, São Paulo, Brazil. Master's thesis, The University of Florida, FL, USA.

Daily, G.C., Ceballos, G., Pacheco, J., Suzán, G. \& SánchezAzofeifa, A. (2003) Countryside biogeography of Neotropical mammals: conservation opportunities in agricultural landscapes of Costa Rica. Conservation Biology 17: 1814-1826.

Dunn, M. (2004) Re-interpreting the impacts of indigenous hunting: A participatory geographic analysis of Miskito wildlife use in eastern Honduras. Master's thesis, Carleton University, Ontario, Canada.

Emmons, L.H. (1987) Comparative feeding ecology of felids in a Neotropical rainforest. Behavioral Ecology and Sociobiology 20: 271-283.

Escamilla, A., Sanvicente, M., Sosa, M., \& Galindo-Leal, C. (2000) Habitat mosaic, wildlife availability, and hunting in the tropical forest of Calakmul, Mexico. Conservation Biology 14: 1592-1601.
Forline, L.C. (1997) The persistence and cultural transformation of the Guajá Indians: foragers of Maranhão State, Brazil. Ph.D. dissertation, The University of Florida, Florida, USA.

Gavin, M.C. (2007) Foraging in the fallows: Hunting patterns across a successional continuum in the Peruvian Amazon. Biological Conservation 134: 64-72.

Hames, R. (1979) A comparison of the efficiencies of the shotgun and the bow in Neotropical forest hunting. Human Ecology 7: 219252.

Hill, K. \& Hawkes, K. (1983) Neotropical hunting among the Aché of Eastern Paraguay. In: Adaptive Responses of Native Amazonians, ed. R. Hames \& W. Vickers, pp. 223-267. New York, NY, USA: Academic Press.

Hugh-Jones, S. (1979) The Palm and the Pleiades: Initiation and Cosmology in Northmest Amazonia. Cambridge, UK: Cambridge University Press.

Jorgenson, J.P. (1993) Gardens, wildlife densities, and subsistence hunting by Maya Indians in Quintana Roo, Mexico. Ph.D. dissertation, The University of Florida, Florida, USA.

Kaplan, H. \& Kopischke, K. (1992) Resource use, traditional technology, and change among native peoples of Lowland South America. In: Conservation of Neotropical Forests: Working From Traditional Resource Use, ed. K.H. Redford \& C. Padoch, pp. 83-107. New York, NY, USA: Columbia University Press.

Koshear, J. (1995) Guaymí Agriculture, forest utilization and ethnobotany in Coto Brus, Costa Rica: an analysis of sustainability. Ph.D. dissertation, The University of California, Berkeley, CA, USA.

Koster, J.M. (2006) Assessing the sustainability of Baird's tapir hunting in the Bosawas Reserve, Nicaragua. Tapir Conservation 15: $23-28$.

Koster, J.M. (2007) Hunting and subsistence among the Mayangna and Miskito of Nicaragua's Bosawas Biosphere Reserve. Ph.D. dissertation, Penn State University, PA, USA.

Koster, J.M. (2008a) Hunting with dogs in Nicaragua: An optimal foraging approach. Current Anthropology (in press).

Koster, J.M. (2008b) Kills of giant anteaters (Myrmecophaga tridactyla) by hunters with dogs in the Bosawas Biosphere Reserve, Nicaragua. The Southmestern Naturalist 53: 414-416.

Leeuwenberg, F.J. \& Robinson, J.G. (2000) Traditional management of hunting in a Xavante community in Central Brazil. In: Hunting for Sustainability in Tropical Forests, ed. J.G. Robinson \& E.L. Bennett, pp. 375-394. New York, NY, USA: Columbia University Press.

Lizot, J. (1988) Los Yanomami. In: Los Aborigenes de Venezuela, ed. W. Coppens, pp. 479-583. Caracas, Venezuela: Fundación La Salle de Ciencias Naturales.

Mena, V.P., Stallings, J.R., Regalado, B.J. \& Cueva, L.R. (2000) The sustainability of current hunting practices by the Huaorani. In: Hunting for Sustainability in Tropical Forests, ed. J.G. Robinson \& E.L. Bennett, pp. 57-78. New York, NY, USA: Columbia University Press.

Milner-Gulland, E.J. \& Akçakaya, H.R. (2001) Sustainability indices for exploited populations. Trends in Ecology and Evolution 16: 686692.

Milner-Gulland, E.J., Bennett, E.L. \& the SCB 2002 Annual Meeting Wild Meat Group. (2003) Wild meat: the bigger picture. Trends in Ecology and Evolution 18: 351-357.

Minzenberg, E. (2005) Hunting and household in PDS São Salvador, Acre, Brazil. Ph.D. dissertation, The University of Florida, FL, USA. 
Naughton-Treves, L., Mena, J.L., Treves, A., Alvarez, N. \& Radeloff, V.C. (2003) Wildlife survival beyond park boundaries: the impact of slash-and-burn agriculture and hunting of mammals in Tambopata, Peru. Conservation Biology 17: 1106-1117.

Nietschmann, B. (1990) Conservation by conflict in Nicaragua. Natural History 11: 42-49.

Novaro, A.J., Redford, K.H. \& Bodmer, R.E. (2000) Effect of hunting in source-sink systems in the Neotropics. Conservation Biology 14: 713-721.

Ohl-Schacherer, J., Shepard Jr, G.H., Kaplan, H., Peres, C.A., Levi, T. \& Yu, D.W. (2007) The sustainability of subsistence hunting by Matsigenka native communities in Manu National Park, Peru. Conservation Biology 21: 1174-1185.

Peres, C. (1996) Population status of white-lipped Tayassu pecari and collared peccaries T. tajacu in hunted and unhunted Amazonian forests. Biological Conservation 77: 115-123.

Peres, C. (2000) Effects of subsistence hunting on vertebrate community structure in Amazonian forests. Conservation Biology 14: 240-253.

Pulliam, H. (1988) Sources, sinks, and population regulation. American Naturalist 132: 652-661.

Redford, K.H. \& Mansour, J.A., eds (1996) Traditional Peoples and Biodiversity Conservation in Large Tropical Landscapes. Arlington, VA, USA: America Verde Series of The Nature Conservancy.

Redford, K.H. \& Robinson, J.G. (1987) The game of choice: patterns of Indian and colonist hunting in the Neotropics. American Anthropologist 89: 650-667.

Redford, K.H. \& Sanderson, S.E. (2000) Extracting humans from nature. Conservation Biology 14: 1362-1364.

Robinson, J.G. (2000) Calculating maximum sustainable harvests and percentage offtakes. In: Hunting for Sustainability in Tropical Forests, ed. J.G. Robinson \& E.L. Bennett, pp. 521-524. New York, NY, USA: Columbia University Press.

Robinson, J.G. \& Bennett, E.L. (2004) Having your wildlife and eating it too: an analysis of hunting sustainability across tropical ecosystems. Animal Conservation 7: 397-408.

Robinson, J.G. \& Redford, K.H. (1986a) Intrinsic rate of natural increase in Neotropical forest mammals: relationship to phylogeny and diet. Oecologia 68: 516-520.

Robinson, J.G. \& Redford, K.H. (1986b) Body size, diet, and population density of Neotropical forest mammals. The American Naturalist 128: 665-680.

Robinson, J.G. \& Redford, K.H. (1991) Sustainable harvest of Neotropical forest mammals. In: Neotropical Wildlife Use and Conservation, ed. J.G. Robinson \& K.H. Redford, pp. 415-429. Chicago, IL, USA: University of Chicago Press.

Robinson, J.G. \& Redford, K.H. (1994) Community-based approaches to wildlife conservation in Neotropical forests. In: Natural Connections: Perspectives in Community-based Conservation, ed. D. Western \& R.M. Wright, pp. 300-319. Washington, DC, USA: Island Press.

Romanoff, S.A. (1984) Matses adaptations in the Peruvian Amazon. Ph.D. dissertation, Columbia University, New York, USA.
Salas, L.A. \& Kim, J.B. (2002) Spatial factors and stochasticity in the evaluation of sustainable hunting of tapirs. Conservation Biology 16: 86-96.

Schwartz, M. (1997) A History of Dogs in the Early Americas. New Haven, CT, USA: Yale University Press.

Sirén, A., Hamback, P. \& Machoa, J. (2004) Including spatial heterogeneity and animal dispersal when evaluating hunting: a model analysis and an empirical assessment in an Amazonian community. Conservation Biology 18: 1315-1329.

Smith, D.A. (2003) Participatory mapping of community lands and hunting yields among the Bugle of Western Panama. Human Organization 62: 332-343.

Smith, D.A. (2005) Garden game: shifting cultivation, indigenous hunting and wildlife ecology in western Panama. Human Ecology 33: 505-537.

Smith, N.J.H. (1976) Utilization of game along Brazil's transamazon highway. Acta Amazonia 6: 455-466.

Stearman, A.M. (2000) A pound of flesh: social changes and modernization as factors in hunting sustainability among Neotropical indigenous societies. In: Hunting for Sustainability in Tropical Forests, ed. J.G. Robinson \& E.L. Bennett, pp. 233-250. New York, NY, USA: Columbia University Press.

Stocks, A. (1996) The BOSAWAS Natural Reserve and the Mayangna of Nicaragua. In: Traditional Peoples and Biodiversity Conservation in Large Tropical Landscapes, eds. K.H. Redford \& J.A. Mansour, pp. 1-32. Arlington, VA, USA: America Verde Series of The Nature Conservancy.

Stocks, A. (2003) Mapping dreams in Nicaragua's Bosawas Reserve. Human Organization 62: 344-356.

Stocks, A. (2005) Too much for too few: problems of indigenous land rights in Latin America. Annual Reviem of Anthropology 34: 85-104.

Stocks, A., McMahan, B. \& Taber, P. (2007) Indigenous, colonist, and government impacts on Nicaragua's Bosawas Reserve. Conservation Biology 21: 1495-1505.

Townsend, W.R. (2000) The sustainability of subsistence hunting by the Sirionó Indians of Bolivia. In: Hunting for Sustainability in Tropical Forests, ed. J.G. Robinson \& E.L. Bennett, pp. 267-281. New York, NY, USA: Columbia University Press.

Ventocilla, J., Herrera, H. \& Nuñez, V. (1995) Plants and Animals in the Life of the Kuna. Austin, TX, USA: University of Texas Press.

Vickers, W.T. (1991) Hunting yields and game composition over ten years in an Amazon Indian territory. In: Neotropical Wildlife Use and Conservation, ed. J.G. Robinson \& K.H. Redford, pp. 53-81. Chicago, IL, USA: University of Chicago Press.

Wagley, C. (1977) Welcome of Tears: The Tapirapé Indians of Central Brazil. New York, NY, USA: Oxford University Press.

Williams-Guillén, K., Griffith, D., Polisar, J., Camilo, G. \& Bauman, K. (2006) Abundancia de animales de caza y características de cacería en el territorio indígena de Kipla Sait Tasbaika, reserva de biósfera BOSAWAS. Wani 23: 37-61. 